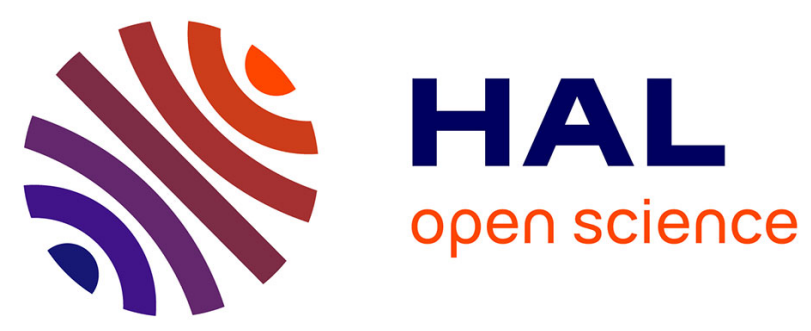

\title{
Cenozoic intracontinental dextral motion in the Okhotsk-Japan Sea Region
}

Laurent Jolivet, Marc Fournier, Philippe Huchon, Vitali S. Rozhdestvenskiy, Konstantin F. Sergeyev, Leonid Oscorbin

\section{- To cite this version:}

Laurent Jolivet, Marc Fournier, Philippe Huchon, Vitali S. Rozhdestvenskiy, Konstantin F. Sergeyev, et al.. Cenozoic intracontinental dextral motion in the Okhotsk-Japan Sea Region. Tectonics, 1992, 11 (5), pp.968-977. 10.1029/92TC00337 . insu-00726600

\section{HAL Id: insu-00726600 https://hal-insu.archives-ouvertes.fr/insu-00726600}

Submitted on 30 Aug 2012

HAL is a multi-disciplinary open access archive for the deposit and dissemination of scientific research documents, whether they are published or not. The documents may come from teaching and research institutions in France or abroad, or from public or private research centers.
L'archive ouverte pluridisciplinaire HAL, est destinée au dépôt et à la diffusion de documents scientifiques de niveau recherche, publiés ou non, émanant des établissements d'enseignement et de recherche français ou étrangers, des laboratoires publics ou privés. 


\section{CENOZOIC INTRACONTINENTAL DEXTRAL MOTION IN THE OKHOTSK-JAPAN SEA REGION}

\author{
Laurent Jolivet, Marc Fournier, and Philippe Huchon \\ Département de Géologie, Ecole Normale \\ Supérieure, Paris, France
}

Vitali S. Rozhdestvenskiy, Konstantin F. Sergeyev, and Leonid S. Oscorbin

Institute of Marine Geology and Geophysics, Far

East Science Center, Yuzhno-Sakhalinsk, USSR

Abstract. A right-lateral shear zone trending northerly along more than $2000 \mathrm{~km}$ is recognized from central Japan to northem Sakhalin. It was active mainly during the Neogene and has accommodated several hundreds of kilometers of displacement. The whole structure of Sakhalin is built on this shear zone. En échelon sigmoidal folds and thrusts, en échelon narrow Miocene basins, and a major discontinuity which is observed along more than 600 $\mathrm{km}$, the Tym-Poronaisk fault, characterize the deformation there. In Hokkaido, en échelon folds and thrusts and a ductile shear zone with hightemperature metamorphism constitute the southern extension of this transpressional shear zone. It continues to the south as a zone of transtensional deformation along the eastern margin of Japan Sea, as en échelon basins and dextral transfer faults observed as far south as Noto peninsula and Yatsuo basin. The style of the shear zone thus evolves from transpressional in the north far from the subduction zone, to transtensional in the south in the back-arc region. Strike-slip motion along this shear zone was primarily responsible for the dextral pull-apart opening of Japan Sea during the early and middle Miocene. Dextral motion is still active in the north along the Tym-Poronaisk fault in Sakhalin as well as on the continental margin of Japan Sea (Korea and Asia mainland). Active E-W compression replaced the dextral motion along the eastern margin of Japan Sea in late Miocene time, and incipient subduction began in the early Quaternary.

\section{INTRODUCTION}

A diffuse zone of active deformation with crustal seismicity runs along Sakhalin, between the Amur region and Okhostk Sea (Figure 1). It has led to various interpretations, they are discussed by Jolivet et al. [1990]. Chapman and Solomon [1976], on the basis of a study of several large earthquakes focal mechanisms, concluded that a zone of active compression was perpendicular to the trend of Sakhalin. They assigned this deformation to the motion of North America (NAM hereafter) relative to

Copyright 1992 by the American Geophysical Union

Paper number $92 \mathrm{TC} 00337$

0278-7407/92/92TC-00337 \$10.00
Eurasia (EUR hereafter). The rotation pole is located in eastern Siberia; north of it, extension prevails along the Cherskyi ranges, and oceanic spreading is active along the Gakkel-Nansen ridge, which is the northernmost extension of the Mid-Atlantic ridge. Savostin et al. [1983] instead proposed dextral motion between the Okhotsk and Amurian blocks and a kinematic interpretation taking into account the major structures of northeast Asia such as the Stanovoy ranges (see also Savostin and Karasik [1981], and Cook et al. [1986]).

This active zone extends southward in Hokkaido and along the eastern margin of Japan Sea. Large shallow earthquakes occur frequently there (Figures 2 and 3); they are all of reverse fault type with E-W direction of compression [Fukao and Furumoto, 1975]. Nakamura [1983] proposed that it corresponds to the southward extension of the NAMEUR plate boundary following Chapman and Solomon [1976].

This active zone also corresponds to a domain which has suffered deformation since Oligocene time. Kimura et al. [1983] proposed that dextral oblique collision along the Okhotsk-Amur plate boundary was responsible for the Tertiary structures, such as en échelon folds in Hokkaido and Sakhalin. Jolivet and Miyashita [1985], Jolivet and Huchon [1989], and Jolivet et al. [1990] showed that dextral shear can be recognized along the central belt of Hokkaido (Hidaka Shear Zone) as well as the eastern margin of Japan Sea for lower to middle Miocene time. Lallemand and Jolivet [1985], Kimura and Tamaki [1986], and Jolivet [1986] proposed that this shear zone has been responsible for the dextral pullapart opening of Japan Sea in Miocene time (Figure 1). Large dextral motions along N-S trending shear zones are usually not taken into account when describing the deformation of Asia except by Kimura and Tamaki [1986], Jolivet [1986], Chen and Nabelek [1988], or Jolivet et al. [1990].

In this paper, we present a synthesis of our studies based upon field surveys along this active zone from central Japan to Sakhalin, Landsat imagery, and focal mechanism of earthquakes. Detailed work will be published separately. A new tectonic map of the entire fault zone is described. We show that in Miocene time, structures located along this 2000-km-long shear zone are compatible with a localized dextral shear zone which evolves from transpressional in the north to transtensional in the south in the back-arc region. We discuss its relation to the opening of the Japan Sea back-arc basin. We also briefly discuss the significance of the dextral motions in the overall deformation of eastern Asia.

\section{GENERAL TECTONIC CONTEXT}

In the back-arc region of the Pacific subduction zone, behind the Kuril trench, Sakhalin is a long island extending along some $1000 \mathrm{~km}$ between the Okhotsk Sea and the Tartar strait (Figures 1-3). It does not exceed $200 \mathrm{~km}$ in width and is as narrow as $30 \mathrm{~km}$ at $48^{\circ} \mathrm{N}$. It is the northern extension of the 

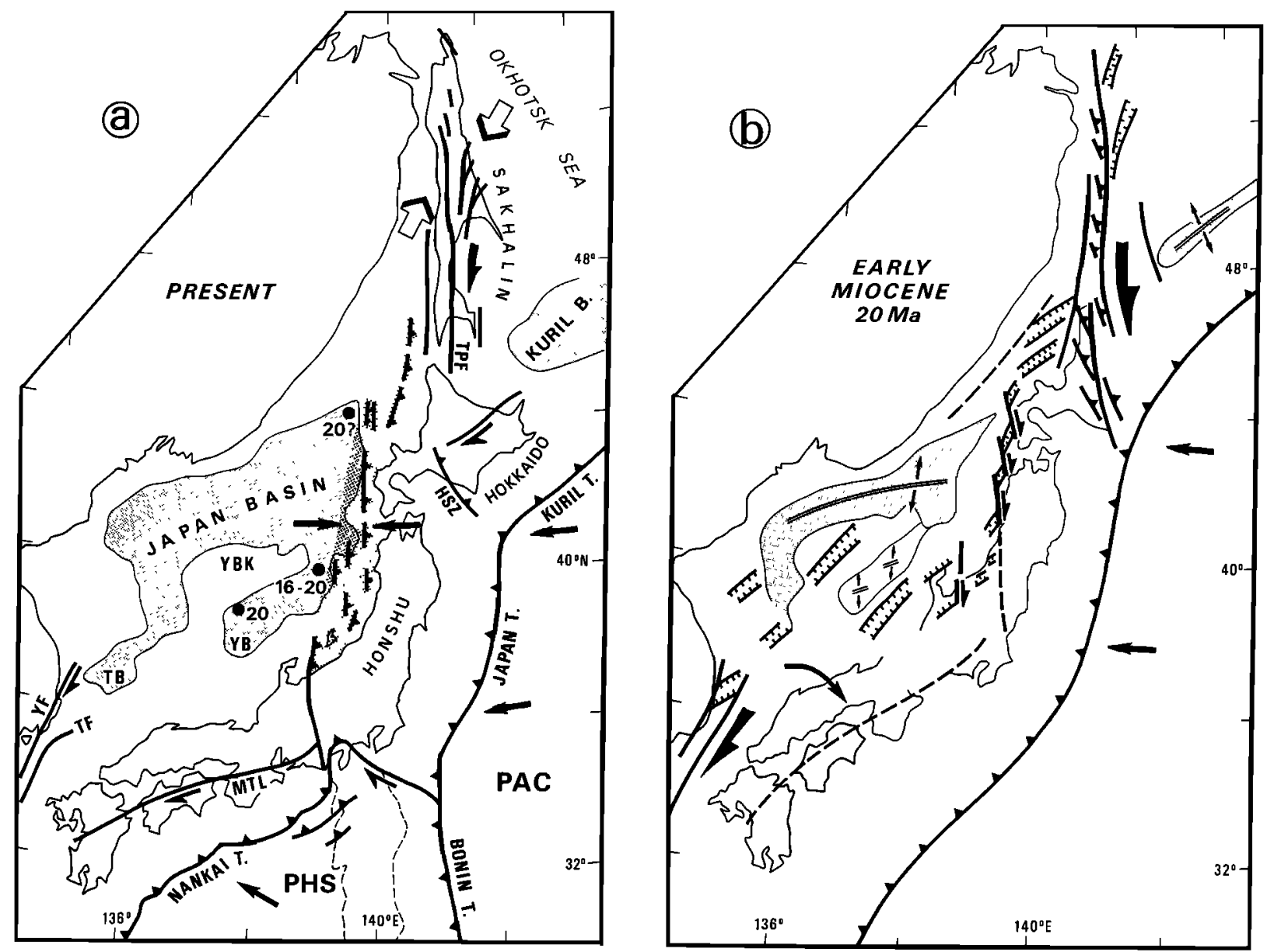

Fig. 1. (a) Present-day geodynamic context of Sakhalin and Japan Sea region. Shaded area represent the oceanic crusts of the Japan Sea and Kuril Basin. Dotted area is the zone of active compression of the eastern Japan Sea. (b) Same region 20 m.y. ago.

Reconstruction parameters are after Jolivet et al. [1991] and Jolivet and Tamaki [1992]. Abbreviations are TPF, Tym-Poronaisk fault; HSZ, Hidaka Shear Zone; MTL, Median Tectonic Line; YBK, Yamato Bank; YB, Yamato basin; YF, Yangsan Fault; TB, Tsushima basin; TF, Tsushima fault; PAC, Pacific plate; and PHS, Philippine Sea plate.

central range of Hokkaido in northern Japan. It is separated from the Asian mainland by the shallow water Tartar Strait, which is the northernmost part of the Japan Sea. To the east, the Okhostk Sea has a continental basement cut by numerous faults making submarine ridges and troughs [Margulis et al., 1979; Gnibidenko, 1985]. In the southern part of the Okhotsk Sea is the Kuril basin, which is floored with thick Cenozoic sediments and oceanic crust possibly of Miocene age [Kimura and Tamaki, 1985]. To the west the Tartar strait is floored with thinned continental crust cut by N-S trending faults and blanketed by a thick sedimentary cover up to $8 \mathrm{~km}$ [Antipov et al., 1980; H. S. Gnibidenko et al., manuscript in preparation, 1992]. Further south, the Japan Sea is divided into three major basins floored with oceanic crust (Japan basin, deeper than $3 \mathrm{~km}$ ) or highly intruded thinned continental crust (Yamato and Tsushima basins, deeper than $2 \mathrm{~km}$ ) [Tamaki, 1985, 1988; Tamaki et al., 1990].

The Kuril trench continues to the south as the Japan trench until its junction with the Bonin trench south of the trench-trench-trench triple junction between the Philippine Sea (PHS hereafter), Pacific (PAC hereafter), and EUR plates [Huchon and Labaume, 1989]. The Pacific plate subducts westward at a velocity of about $10 \mathrm{~cm} / \mathrm{year}$ [Seno, 1985]. The Philippine Sea plate subducts below southwest Japan at slower rate $(4 \mathrm{~cm} /$ year) [Ranken et al., 1984; Huchon, 1986].

Active deformation is recorded along the eastern margin of Japan Sea, Hokkaido and Sakhalin as a diffuse seismic zone [Fukao and Furumoto, 1975; Tamaki, 1988]. Deformation is also recorded in the Tsushima strait [Jun, 1990], between Kyushu and Korea, as well as on the continental side of Japan 


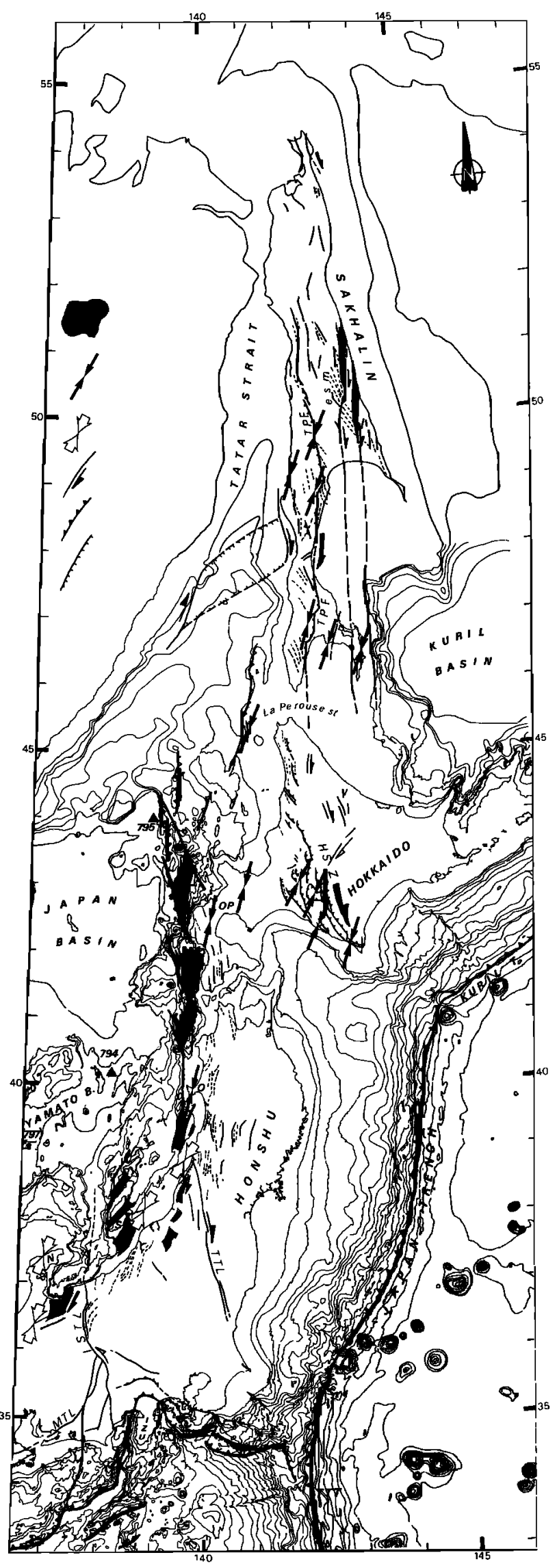

Sea in the Bohai gulf region along major strike-slip dextral faults [Chen and Nabelek, 1988].

The Japan Sea opened during the early and middle Miocene as was recently shown by the results of Ocean Drilling Program legs 127 and 128, which encountered oceanic crust about 20 m.y. old [Tamaki, 1990; Suyehiro et al., 1990]. Figures 2 and 3 show the position of sites 794, 795 and 797 where oceanic basaltic sills were recovered and dated, with the corresponding ages after Kaneoka et al. [1992].

In the region of the trench-trench-trench triple junction, the Bonin arc collides with central Japan north of the Izu peninsula, and active intraoceanic thrusting occurs south of the Nankai trench along the Zenisu ridge [Le Pichon et al., 1987; Chamot-Rooke and Le Pichon, 1989; Lallemant et al., 1989; Taira et al., 1989]. Between the collision zone and the triple junction, right-lateral motion is active along the Sagami trough. The relative motion of PHS relative to Japan has changed drastically since $2 \mathrm{Ma}$ [Huchon, 1985; Jolivet et al., 1989]. The direction of the PHS-EUR motion vector was more northerly during Neogene and then turned to NW.

We now describe the structures observed along the entire deformed domain from south to north. We distinguish two zones of deformation. One is the eastern margin of Japan Sea sensu stricto (northeast Honshu, west Hokkaido, and offshore until Moneron island west of Sakhalin); the other one is the Central belt of Hokkaido and Sakhalin.

\section{EAST JAPAN SEA}

\section{Late Miocene to Present}

E-W compression is active along the eastern margin of Japan Sea. The most spectacular evidence is given by frequent large earthquakes and active faults recorded offshore Honshu, Hokkaido, and Sakhalin [Fukao and Furumoto, 1975; Tamaki, 1988]. Figures 2 and 3 show that this zone extends from the Japan Sea coast of central Japan to the west of Sakhalin. Fault plane solutions indicate E-W compression and pure reverse fault mechanisms. These earthquakes are associated with N-S trending active reverse faults. These are associated with the

Fig. 2. Tectonic map of the entire shear zone: 1 , oceanic crust; 2 , en échelon extensional basins of Miocene age; 3 , direction of Miocene maximum compression deduced from fault set analysis; 4 , sameas for 3 but intermediate compression; 6 , strikeslip faults; 7, thrust faults; and 8, normal faults. Abbreviations are esm, East Sakhalin Moutains; OP, Oshima peninsula; $\mathrm{O}$, Oga peninsula; $\mathrm{N}$, Noto peninsula; IZU, Izu peninsula, TPF, Tym-Poronaisk Fault; MTL, Median Tectonic Line; TTL, Tanakura Tectonic Line; ISTL, Itoigawa-Shizuoka Tectonic Line; HSZ, Hidaka Shear Zone, and TTT: trenchtrench-trench triple junction of Central Japan. 


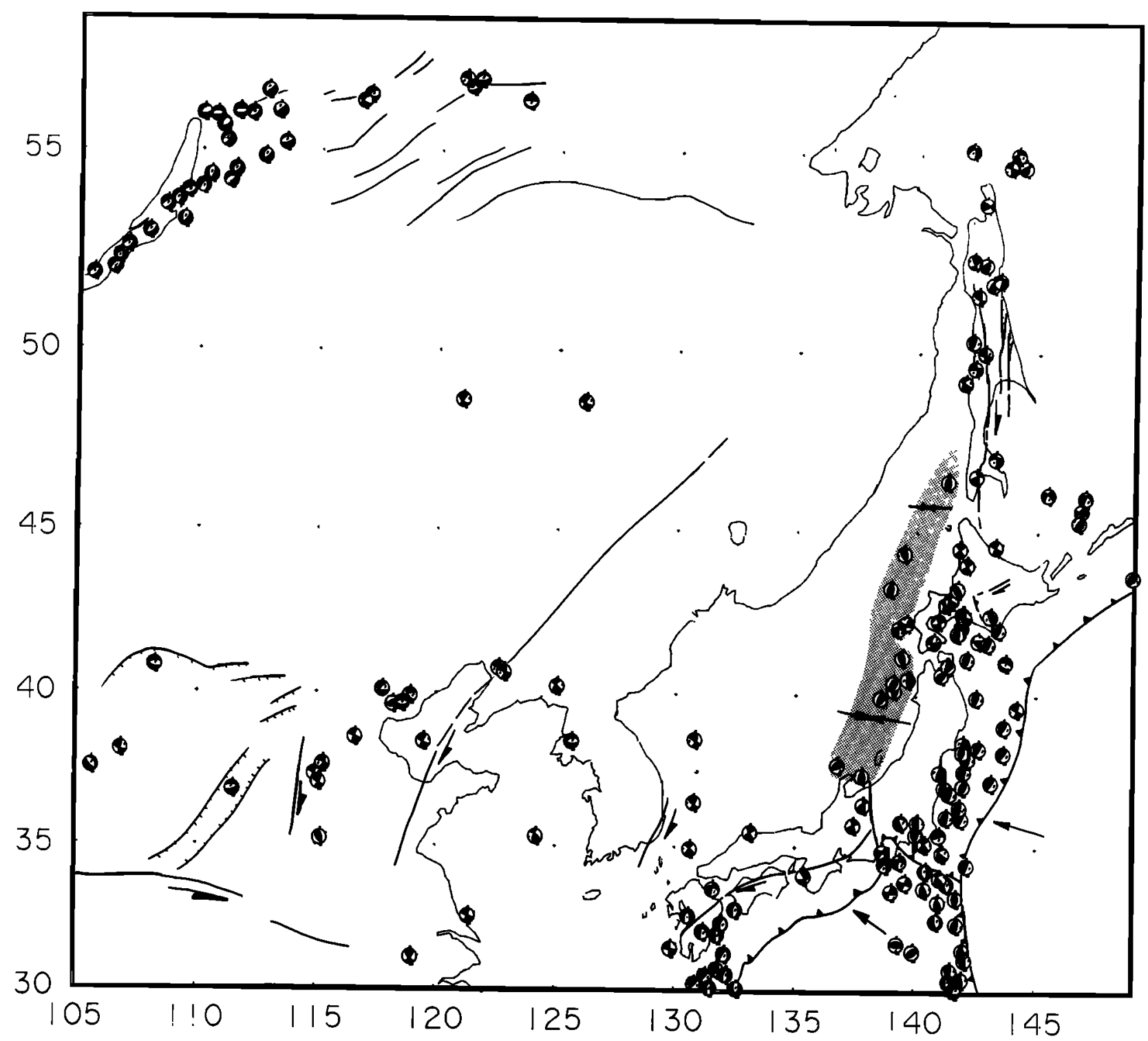

Fig. 3. Compilation of crustal earthquakes focal mechanisms (compressional quadrant in black). After Savostin et al. [1981], Dziewonski et al. [1983], L. S. Oscorbin [unpublished data, 1977], Chen and Nabelek [1988], Jun [1990]. Shaded area represents the zone of E-W compression in the eastern Japan Sea.

reactivation of Neogene en échelon basins [Jolivet et al., 1991]. Active thrust faults uplift narrow ridges of oceanic crust such as the Okushiri ridge [Tamaki, 1988]. Deep drilling on the ridge during ODP leg 127 revealed that the coarse-grained detrital supply stops on the ridge at $1.8 \mathrm{Ma}$ because the ridge was uplifted above the bottom of the basin at this time [Tamaki et al., 1990]. This age is interpreted as the inception of subduction of Japan Sea lithosphere.

Active deformation is observed also onland where Neogene deposits are folded with N-S trending fold axes and thrusts [Amano and Sato, 1989; Sato, 1989]. Early studies of vertical movements of the northeast Honshu arc reveal a period of upheaval from 5 Ma to the present [Sugi et al., 1983]. The paleostress field inferred from dike orientation changes to E-W compression at $7 \mathrm{Ma}$ [Nakamura and Uyeda, 1980; Takeuchi, 1985]. Neogene subsidence curves on the margins of Japan Sea and at oceanic sites show uplift from $10 \mathrm{Ma}$ to the present [Ingle, 1992]. Observation of fault sets in the Neogene deposits of western Hokkaido and northeast Honshu indicates a change of maximum horizontal compression from NE-SW to E-W between the middle and late Miocene [Jolivet and Huchon, 1989; Yamagishi and Watanabe, 1986; Otsuki, 1989]. The age of beginning of E-W compression can thus be determined to have occurred around $9 \mathrm{Ma}$. 


\section{Early and Middle Miocene Deformation}

This active deformation reworks a zone of Miocene transtension. The en échelon geometry of Quaternary compressional basins is not compatible with the present stress field. Because a Miocene graben crops out on Sado island which is parallel to the en échelon basins, it is likely that they all correspond to Miocene extensional basins. Their en échelon position is then compatible with a dextral oblique extension [Jolivet et al., 1991]. A similar geometry is observed onland in the Uetsu district, where fast rifting is observed to have occurred in the early Miocene [Yamaji, 1989; 1990]. In general the age of rifting on the eastern margin of Japan Sea is considered to be early to middle Miocene [Suzuki, 1989; Amano and Sato, 1989]. The age of formation of the oceanic basin offshore NE Honshu has been recently revealed by ODP leg 127: at site 794 and 797 early Miocene ( $20 \mathrm{Ma}$ to $16 \mathrm{Ma}$ ) basalts were recovered as sills interbedded with deep water sediments. Intense basaltic intrusive and extrusive activity, around $15 \mathrm{Ma}$, is recognized in the Aosawa region onland NE Honshu [Tsuchiya, 1989, 1990].

Fault set analysis indicates that NW-SE extension prevailed with association of normal and strike-slip faults until the end of the middle Miocene in NE Honshu and Sado island [Jolivet et al., 1991]. Additional observations confirm this geometry in the Noto peninsula and Yatsuo basin further south (Figure 3). All fault set data from Sakhalin to Yatsuo basin will be published separately [Fournier et al., paper submitted to Joumal of Geophysical Research, 1992]. Right-lateral shear is not restricted to the Japan Sea coastal area, since Cretaceous left-lateral shear zones such as the Tanakura Tectonic Line were reactivated in Miocene time as dextral faults [Koshiya, 1986].

The direction of horizontal maximum compression of Miocene age remains constant from Yatsuo to Rebun island, but it corresponds to $\sigma_{2}$ (intermediate principal stress) in the south and $\sigma_{1}$ in the north. In Rebun island and Hokkaido, NE trending compression prevails with strike-slip and reverse faults [Jolivet and Huchon, 1989].

To summarize, the eastern margin of Japan Sea was the site of dextral oblique extension in early and middle Miocene time. Meanwhile, oceanic spreading was occurring in Yamato and Japan basins. By the end of the middle Miocene a sharp change in stress field occurred. E-W compression took place on the same zone. By the early Quaternary, subduction began, and thrust faults affected the oceanic back-arc region.

\section{HOKKAIDO CENTRAL BELT}

\section{Late Miocene to Present Deformation}

The N-S trending Hokkaido central belt was built through polyphase evolution from the Mesozoic to the present. A drastic change in the deformation regime occurred at the end of the middle Miocene as far south as Honshu. Recent evolution is characterized by E-W compression and fast uplift of the metamorphic core of the belt, the Hidaka mountains [Kimura et al., 1983]. Steep N-S trending thrusts separate it from the foreland to the west, where active thrusting affects Pliocene and recent sediments of the Sapporo-Tomakomai depression [Mitani, 1978; Yamagishi and Watanabe, 1986].

\section{Oligocene to Middle Miocene deformation}

An older stage of deformation prior to the E-W compression is recognized only in sediments older than late Miocene; reverse and strike-slip faults are associated with this stage [Jolivet and Huchon, 1989]. The maximum horizontal compression trends NE consistently from south to north. This stage is characterized by the formation of NW trending en échelon folds and thrusts in the nonmetamorphic zones [Kimura et al., 1983] and a ductile shear zone (Hidaka Shear Zone) in the metamorphic zone. Jolivet and Miyashita [1985] interpreted this ductile deformation as the result of dextral shear in a deep crustal environment. Jolivet and Huchon [1989] related the en échelon folds and thrusts and the ductile shear zone to a crustal-scale half flower structure built along a transpressional dextral strikeslip crustal fault of Oligocene to middle Miocene age. This interpretation is roughly consistent with that of Kimura et al. [1983] in terms of kinematics (dextral oblique collision). Recent paleomagnetic investigations in Hokkaido confirm this interpretation [Kodama et al., 1990]. The dextral transpression is observed till Rebun island on the Japan Sea margin offshore northernmost Hokkaido. East of the Hokkaido central belt, N-S trending dextral faults are related to the formation of small pull-apart basins in Miocene time [Watanabe and Iwata, 1985; Watanabe, 1988].

\section{SAKHALIN}

The Hokkaido central belt extends northward through Sakhalin island. East Sakhalin Mountains is a tectonic map of Sakhalin derived from the existing geological map at 1/1000000 scale, Rozhdestvenskiy [1983, 1986], K. F. Sergeyev (unpublished data, 1990) and our own field observations and Landsat images analysis. The most prominent structure is the Tym-Poronaisk fault, which runs N-S for more than $600 \mathrm{~km}$. Other N-S trending faults are recognized east of the Tym-Poronaisk fault, but they are probably less active. Following Rozhdestvenskiy [1982] and Kimura et al. [1983] we recognize in Sakhalin the same dextral strike-slip deformation already described in Honshu and Hokkaido, but the recent $\mathrm{E}-\mathrm{W}$ compression does not show obviously in the structures.

\section{Neogene Deformation}

Figure 4 summarizes the Cenozoic structures of Sakhalin, and Figure 5 shows the features seen on 


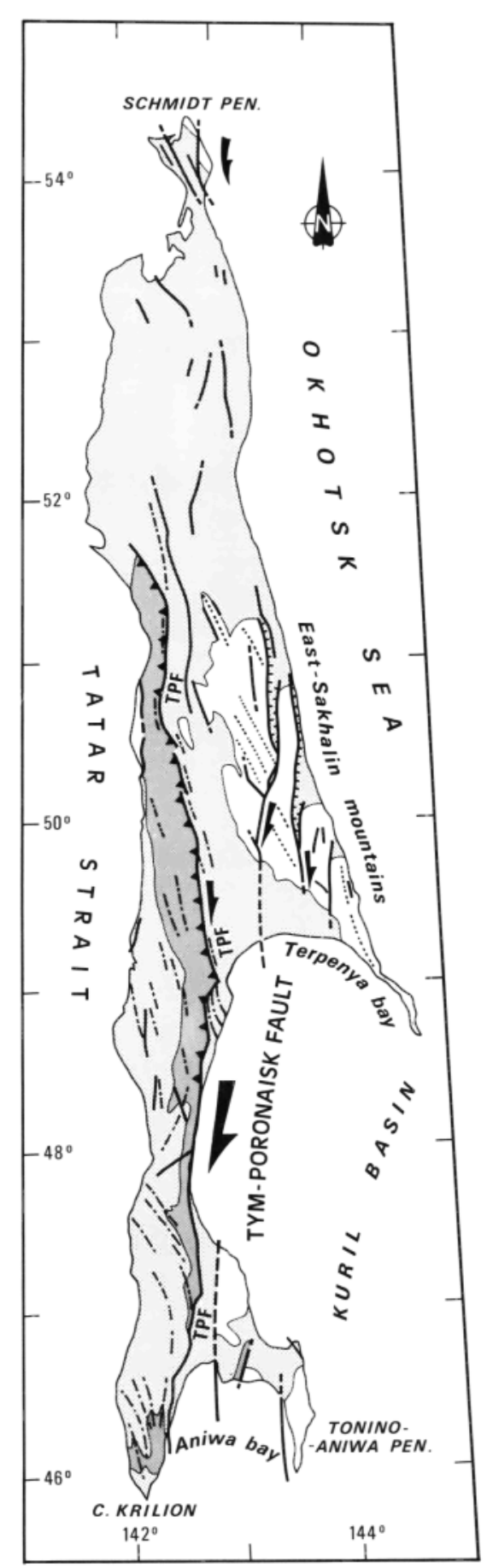

Fig. 4. Tectonic map of Sakhalin after the geological map of Sakhalin, Rozhdestvenskiy [1982], analysis of Landsat images (M. Fournier et al., paper submitted to Journal of Geophysical research, 1992) and K. F. Sergeyev (unpublished data, 1990). Dashed lines are Cenozoic folds axes seen in the Cretaceous to Miocene sediments; dotted lines are axes of postfoliation open folds seen in the Mesozoic metamorphic complex of the Eastern Sakhalin Mountains. the Landsat mosaic as well as focal mechanisms of shallow earthquakes. The Tym-Poronaisk fault divides Sakhalin in two parts: West Sakhalin Mountains and East Sakhalin Mountains.

The Cenozoic sequence is roughly similar on both sides of the fault. It begins in the upper Oligocene with coarse conglomerate and fines upward into lower Miocene sandstone and middle Miocene siltstone and siliceous claystone [Melnikov, 1987]. The whole sequence is intruded by basic dykes and sills, and basaltic lavas and breccia constitute the end of the middle Miocene. The late Miocene and Pliocene are made of tuffaceous siltstone and sandstone.

The West Sakhalin Mountains represent the northern extension of the central belt of Hokkaido; in general facies are similar to those of the Central Belt though less deep in general [Melnikov, 1987]. The Cretaceous is represented by forearc deposits with abundant terrestrial and volcanic detritus. In the East Sakhalin Mountains, Cenozoic deposits are underlain by a complex system of thrusts slices composed of oceanic material of Late Jurassic to Cretaceous age, partly metamorphosed under high-pressure lowtemperature conditions [Rozhdestvenskiy, 1986]. G. Kimura et al. (manuscript in preparation, 1992) describe this system as a Cretaceous accretionary complex. It is the northern extension of the Kamuikotan zone of Hokkaido.

West of the fault and immediately east of it, Cretaceous and Cenozoic sediments are folded; the NW trending axes of the folds distributed with a dextral en échelon pattern [Rozhdestvenskiy, 1982; Melnikov, 1987]. The folds axes are curved close to the fault, thus giving a sigmoidal shape compatible with dextral displacement. The fault is a very sharp feature clearly seen on Landsat images. The fault plane itself occurs between Cretaceous sediments or lavas and Miocene sandstones. It is usually a N-S trending vertical plane with horizontal striation and evidence of dextral motion. In the East Sakhalin Mountains, N-S trending steep faults (Central, Pribrezhnaya, and Liman faults) cut through the Mesozoic accretionary complex. They are associated with narrow Miocene sedimentary basins which are arranged en échelon. A small dextral pull-apart basin is seen on Landsat images along the North-Sakhalin fault. Rozhdestvenskiy [1982] shows that the contact between a metamorphic complex and nonmetamorphosed sediments is offset dextrally by $25 \mathrm{~km}$. Dextral offset along N-S trending faults is also observed in Schmidt peninsula in the very north of Sakhalin.

We performed fault set analysis along and around the Tym-Poronaisk fault. All data are compatible with NE trending horizontal compression (Figures 2 and 5). Fault set analysis [Fournier et al., paper submitted to Journal of Geophysical Research, and Figure 5] shows an E-W trending compression at several sites along the fault, it is however always associated with curved fold axes with the dextral en échelon pattern. The direction of compression is 


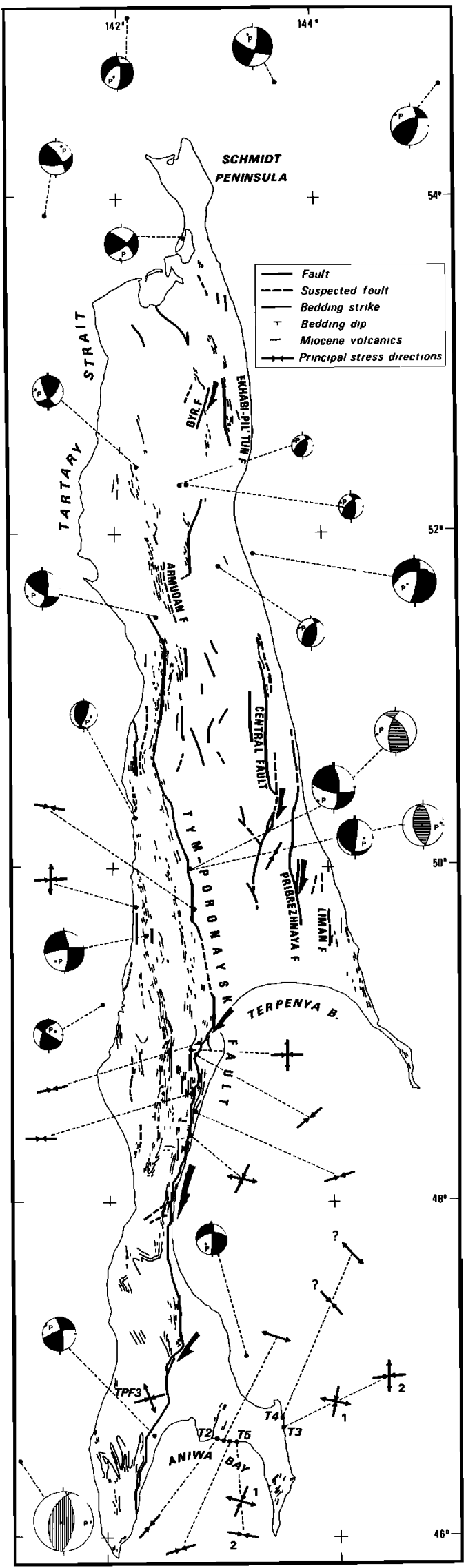

elsewhere NE-trending and always perpendicular to fold axes. E-W compression therefore corresponds to rotated sites and the original direction of compression (Figure 2) was thus NE. This is in good agreement with the trend of fold axes and strike-slip faults.

Our observations of the deformation in the accretionary complex below the Cenozoic deposits of the East Sakhalin Mountains reveal a first stage with layer-parallel shear of probable Mesozoic age [Kimura et al., in prep.] followed by a second stage of upright foling. These folds trend NW and are compatible with the same NE trending compression which gave the en échelon folds of West Sakhalin. We thus attribute these folds also to the Cenozoic stage and the strike-slip motion.

A recent compilation of seismic data allowed $\mathrm{H}$. S. Gnibidenko et al. (manuscript in preparation , 1992] to draw a precise isopach map of Cenozoic sediments in the Tartar Strait. One prominent feature is a deep rhombohedral basin (Figure 2) bounded by NS-trending vertical compressional faults and NE trending normal faults and filled with more than $8 \mathrm{~km}$ of Cenozoic deposits. The overall shape of the basin and the nature of the faults lead us to the conclusion that it corresponds to a dextral pull-apart. This shows that a large part of the dextral motion was localized in the Tartar Strait.

\section{Active Deformation}

Fault plane solutions of earthquakes in Sakhalin (L. S. Oscorbin, unpublished data) show two kinds of mechanisms (Figures 3 and 5), both being

Fig. 5. Map of Sakhalin showing the features seen on the Landsat mozaic after M. Fournier et al. (paper submitted to Journal of Geophysical Research, 1992). Paleo-stress-field horizontal directions deduced from fault set analysis are plotted. Fault plane solutions of superficial earthquakes (depth lower than $30 \mathrm{~km}$ ) determined by L. S. Oscorbin (Tquadrants in black), and Fukao and Furumoto [1975] (T-quadrants vertically ruled) and centroid moment tensors determined by Dziewonski et al. [1985, 1987] (T-quadrants horizontally ruled) are shown. Radii of focal mechanisms are a function of the magnitude (surface waves) of earthquakes except for Dziewonski et al. [1985, 1987]. Concerning Oscorbin data, we kept the main event only when two focal mechanisms were determined for the same earthquake. The two centroid moment tensors determined by Dziewonski et al. [1985, 1987] correspond to two earthquakes which fault plane solutions have independantly been determined by Oscorbin (in order to simplify we indicate only Oscorbin 's epicenter locations). P axes are almost similar in each case, and $\mathrm{T}$ axes of Diewonski et al.s focal mechanisms are steeper so that they indicate compressional motion when Oscorbin's indicate strike-slip motion. 
compressional: strike-slip and reverse faults. Several mechanisms located close to the main fault trace are compatible with dextral motion along the fault. Rozhdestvenskiy [1986] describes a change in the stress pattern in Pliocene time from dextral wrench along the Tym-Poronaisk fault to E-W compression. As described above, the fault set analysis does not reveal E-W compression except perhaps in the south, and all structures observed at large scale are compatible with dextral motion. The existence of dextral fault plane solutions lead us to think that dextral wrench is still active in Sakhalin, as already stated by Savostin et al. [1983].

\section{DISCUSSION}

From central Japan to the north of Sakhalin, along more than $2000 \mathrm{~km}$, we recognize a narrow domain of strain localization with evidence of dextral motion in Miocene time. It is thus a major feature of the deformation of eastem Asia, and it is worth discussing its evolution with time.

\section{Present-Day Activity}

Although E-W compression is obvious in the south, in the back-arc region, with numerous large compressional earthquakes and other compressional features, it is not as clear in the north. Dextral motion is probably still active in Sakhalin, except in the very south (the Moneron earthquake is similar to those off Hokkaido and Honshu and corresponds to the northernmost extension of the East Japan Sea nascent subduction zone).

\section{Miocene Deformation}

In the north the strike-slip deformation is transpressional and localized along a very narrow zone, characterized by en échelon folds and thrusts and one major discontinuity, the Tym-Poronaisk fault. Further south it becomes more transpressional in the Hidaka mountains where the shear zone curves toward a more westerly trend. Ductile parts of the shear zone were there uplifted during the dextral shear. This transpressional zone continues in the southwest as a transtensional one along the eastern margin of Japan Sea. It is characterized by en échelon graben and dextral transfer faults which were later reactivated as compressional structures. The dextral shear in Hokkaido and Japan Sea margin ended about 10 m.y. ago and is contemporaneous with the deposition of early to middle Miocene sediments. It is thus exactly contemporaneous with the opening of Japan Sea. Figure 1b shows a reconstruction of the strike-slip shear zone in early Miocene time during an early stage of Japan Sea opening [after Jolivet et al., 1991; Jolivet and Tamaki, 1992]. It is contemporaneous with the rotation of SW Japan deduced from paleomagnetic data [Otofuji et al., 1985]. The dextral shear zone extends to the south as a dextral fault between SW Japan and Korea [Sillitoe, 1977].
Therefore, if the dextral motion is correlated with the Japan Sea opening, several hundred kilometers of dextral displacement are expected. Reconstructions of the pre-opening situation [Jolivet and Tamaki, 1992] show a total offset since $25 \mathrm{Ma}$ of about 400 $\mathrm{km}$. There is no direct evidence concerning the total dextral offset. Only Rozhdestvenskiy [1982] describes a $25-\mathrm{km}$ offset along one fault in the East Sakhalin Mountains. As the deformation is distributed on several major faults the total displacement is most likely much larger. The TymPoronaisk, being the major onshore fault, probably accommodated the largest displacement but certainly not more than a few tens of kilometers. So, the largest part of the dextral motion must be taken up along the Tartar Strait where the crust is thinner.

It is noticeable that the dextral shear zone is nowhere compatible with the PAC-EUR relative motion. Furthermore, it extends northward very far from the subduction zone and trends at a large angle to the trench system. It is thus unlikely that it represents a back-arc strike-slip fault such as the Philippine or Sumatra faults which accommodate the obliquity of the motion vector [Huchon and Le Pichon, 1984]. Such obliquity is observed in the Kuril trench at present and is accommodated by a ENE-WSW dextral fault parallel to the Kuril arc, which cuts through eastern Hokkaido [Kimura, 1986]. It is almost perpendicular to the trend of the major dextral shear zone.

The dextral shear zone was tumed into a compressional zone in the back-arc region about 10 m.y. ago. This date corresponds to the end of the Japan Sea opening and is slightly younger than the arrival of the triple junction in its present position [Jolivet et al., 1989]. The compression is restricted to the back-arc region north to the central Japan triple junction. Far off the triple junction, either in Sakhalin or in Korea, and also on the continental side of Japan Sea, the deformation is still dextral (Figure 3) [Chen and Nabelek, 1988; Jun, 1990]. South of the triple junction, extension is active in the Bonin arc. This suggests that compression is due to the local plate configuration in the triple junction region and/or the degree of plate coupling along the subduction zone and is not characteristic of the more general tectonic context of eastern Asia. Following Kimura and Tamaki [1986] and Jolivet et al. [1990], we suggest that the Sakhalin-East Japan Sea is one of the major dextral faults created in the Asian continent during the India-Asia collision. Figure 3 shows that other dextral faults which are still active, exist west of it. Chen and Nabelek [1988] showed that dextral motion has been active in the Bohai gulf region along NNE trending faults. Jun [1990] describes focal mechanisms along the Tsushima fault which are compatible with dextral shear. This shear zone reactivated in Miocene time the Mesozoic suture that runs along Hokkaido and Sakhalin. Far from the subduction zone it was, and still is, a transpressional wrench fault, and it turned to a transtensional one in the back-arc region because extensional tectonics was prevailing there. At that time all major back-arc 
basins were opening (Japan Sea, Shikoku basin, South China Sea, and possibly Kuril basin), which indicates that extensional conditions were active all along the western Pacific margin behind the subduction zone. The formation of this strike-slip shear zone disturbed the back-arc extension, giving rise to the pull-apart geometry we now observe. Extension in the back-arc region was linked with the mechanics of stress coupling along the subduction zone, and strike-slip with internal deformation of Asia due to collision with India.
Aknowledgements: Special thanks are due to Helios Gnibidenko, Rimma Kovalenko, and Oleg Melhnikov for their warm welcome in YuzhnoSakhalinsk, and for field guidance and useful comments. We also wish to express our thanks to Gaku Kimura and Koji Okumura, who were our partners during the field survey in Sakhalin. This study was funded by Centre National de la Recherche Scientifique-Institut National des Sciences de l'Univers (programme Dynamique et Bilan de la Terre, DBT). This paper is DBT contribution 417.

\section{REFERENCES}

Amano, K. and H. Sato, Neogene tectonics of the central part of northeast Honshu arc, Mem. Geol. Soc. Jpn., 32, 81-96, 1989.

Antipov, M.P., V.M. Kovylin, and V.P. Filatye Sedimentary cover of the deep water basins of Tatar strait and the northem part of the sea of Japan, Int. Geol. Rev., 22, 1327-1334, 1980.

Chamot-Rooke, N., and X. Le Pichon, Zenisu ridge: mechanical model of formation, Tectonophysics, 160, 175-194, 1989.

Chapman M. C., and S. C. Solomon, North American-Eurasian plate boundary in northeast Asia, J. Geophys. Res., 81, 921-930, 1976.

Chen, W. P. and J. Nabelek, Seismogenic strikeslip faulting and the development of the North China basin, Tectonics, 7, 975-989, 1988.

Cook, D.B., K. Fujita, and C. A. Mac Mullen, Present day plate interactions in northeast Asia: North America, Eurasian and Okhotsk plates. J. Geodyn., 6, 33-51, 1986.

Dziewonski, A. M., A. Friedman, D. Giardini, and J.H. Woodhouse, Global seismicity of 1982: centroid moment tensor solutions for 308 earthquakes, Phys. Earth Planet. Int., 45, 1136, 1983.

Dziewonski, A. M., J. E. Franzen, and J. H. Woodhouse, Centroid-moment tensor solutions for October-December 1984, Phys. Earth Planet. Inter., 39, 147-156, 1985.

Dziewonski, A. M., G. Ekstrom, J. E. Franzen, and J. H. Woodhouse, Global seismicity of 1979 : centroid-moment tensor solutions for 524 earthquakes, Phys. Earth Plonet. Inter., 48. 1846, 1987.

Fukso, Y., and M. Furumoto, Mechanisms of large earthquakes along the eastem margin of the Japan sea, Tectonophysics, 25, 247-266, 1975.

Gnibidenko, H. S., The Sea of Okhotsk-Kuril islands ridge and Kuril-Kamchatka trench, in The Ocean Basins and Margins, vol. 7A, edited by A.E.N. Naim et al., pp. 377-418, Plenum, New York, 1985.

Huchon, P., Geodynamique de la zone de collision $d$ Tau et du point triple du Japon Central, Thèse de Doctorat, Univ. Pierte el Marie Curie, Paris, 414 pp.,1985.

Huchon, P., Comment on "Kinematics of the Philippine sea plate" by B. Ranken, R. K. Cardwell and D. E. Karig. Tecronics, 5, 165 $168,1986$.

Huchon, P., and P. Labsume, Central Japan triple junction: a three-dimensionsl compression model, Teclonophysics, 160, 117-133, 1989.

Huchon, P. and X. Le Pichon, Sunda strait and Central Sumatra Fault, Geology, 12, 668-672, 1984.

Ingle, J. C., Subsidence of the Japan Sea: evidence from ODP sites and onshore sequences, In
Tamaki, K., Suyehiro, K., Allan, J. et al., 1992, Proc. ODP, Sci. Results, 127-128, in press, 1992.

Jolivet, L., America-Eurasia plate boundary in eastem Asia and the opening of marginal basins. Earth Planet. Sci. Lett., 81, 282-288, 1986.

Jolivet, L. and P. Huchon, Crustal scale strikeslip shear zone in Hokkaido, Northeast Japan, J. Siruct. Geol., 11, 509-522, 1989.

Jolivet, L., and S. Miyashita, The Hidaka Shear Zone (Hokkaido, Japan), genesis during a rightlateral strike slip movement, Tectonics, 4, 289302, 1985.

Jolivet, L., and K. Tamaki, Neogene kinematics in the Japan sea region and volcanic activity of the northeast -Japan arc, In Tamaki, K., Suyehiro, K., Allan, J. el al., 1992, Proc. ODP, Sci. Results, 127-128, in press, 1992.

Jolivel, L., P. Davy, and P. R. Cobbold, Rightlateral shear along the northwest Pacific margin and the India-Eurasia collision, Tectonics, 9, 1409-1419, 1990.

Jolivet, L., P. Huchon, and C. Rangin, Tectonic setting of westem Pacific marginal basins, Tectonophysics, 160, 23-48, 1989.

Jolivet, L., P. Huchon, J. P. Brun, N. ChamotRooke, X. Le Pichon and J.C. Thomas, Arc deformation and marginal basin opening; Japan Sea as a case study, J. Geophys. Res., 96, 4367 . 4384, 1991.

Jun, M. S., Source parameters of shallow intraplate earthquakes in and around the Korean peninsula and their tectonic implication, Acta Univ. Ups. Comp. Swn. of Uppsala Diss. Fac. Sci., 285, 16 pp., 1990.

Kaneoka, I., Takigami, Y., Takaoka, N., Yamashila, S. and Tamaki, K., 40Ar-39Ar analyses of volcanic rocks drilled from the Japan Sea floor by Legs 127/128, In Tamaki. K., Suyehiro, K., Allan, J. et al., 1992, Proc. ODP, Sci. Results, 127.128, in press, 1992.

Kimura, G., Oblique subduction and collision; forearc tectonics of the Kuril arc, Geology, 14, 404-407, 1986.

Kimura, G., and K. Tamaki, Tectonic framework of the Kuril arc since its initiation, in: Formation of Active Ocean Margins, edited by N. Nasu et al., pp. 641-676, Terrapub, Tokyo, 641-676, 1985.

Kimura, G., and K. Tamaki, Collision, rotation and back are spreading; the case of the Okhotsk and Japan seas, Tecionics, 5, 389-401, 1986.

Kimura G., S. Miyashila, and S. Miyasaka, Collision tectonics in Hokkaido and Sakhalin, in Accretion Tectonics in the Circum-Pacific Regions, edited by M. Hashimoto and S. Uyeda, pp. 117-128, Terrapub, Tokyo, 1983.
Kodama, K., T. Takeuchi and T. Ozawa,

Paleomagnetism of Early Cretaceous to Neogene deposits in Central Hokkaido. Japan: block rotation caused by strike-slip fault movement (abstract), Eos Trans. AGU, 71 (28), 865, 1990.

Koshiya, S., Tanakura Shear Zone, the deformation process of fault rocks and its kinemetics, $J$. Geol. Soc. Jpn., 92, 15-29, 1986.

Lallemand, S., and L Jolivet, Japan Sea, a pull apart basin, Earth Planet. Sci. Lett., 76, 375389. 1985.

Lallemant, S., N. Chamot-Rooke, X. Le Pichon, and $C$. Rangin, Zenisu ridge: a deep intraoceanic thrust related to subduction, off Southwest Japan, Teclonophysics, 160, 151-174, 1989.

Le Pichon, X., J. T. Iiyama, J. Boulègue, J. Charvet, M. Faure, K. Kano, S. Lallemant, H. Okada, C Rangin, A. Taira, T. Urabe, and S. Uyeda, Nakai trough and Zenisu ridge: a deep sea submersible survey, Earth Planet. Sci. Letl., 83, 285-299, 1987.

Margulis, L.S., Mudretsov, V.B., Sapozhnikov, B.G., Fedotov, G.D. \& Khvelauk, I.I., 1979, Geological structure of the northwestem part of the sea of Okhotsk. Int. Geol. Rev., 22, 10941102, 1979.

Melnikov, O.A., Structure and geodynamics in Hokkaido and Sakhalin, in Russian, Nauka, 95 pp., 1987.

Mitani, K., Changing of the Tertiary sedimentary basins in the western flank of the axial belt of Hokkaido- bearing a significance of the Sunagawa lowland to Umaoi Hilly belt, Assoc. Geol. Collab. Jpn. Monogr. 21, 127-137. 1978.

Nakamura, K., Possible nascent trench along the eastem Japan sea as the convergent boundary between Eursisia and North American plates (in Japanese with English abstract), Bull. Earthquake Research Inst. Univ. Tokyo, 58, 721-732. 1983.

Nakamura, K. and S. Uyeda, Stress gradient in back arc regions and plate subduction, $J$. Geophys. Res., 85, 6419-6428, 1980.

Otofuji, Y. , T. Matsuda, and S. Nohda, Paleomagnetic evidences for the Miocene counter clockwise rotation of northeast Japan rifting process of the Japan arc, Earth Planet Sci. Lettt., 75, 265-277, 1985.

Otsuki, K., Reconstruction of Neogene tectonic stress field of Northeast Honshu are from metalliferous veins. Mem. Geol. Soc. Jpn., 32 . 281-304, 1989.

Ranken, B., R. K. Cardwell, and D. E. Karig, Kinematics of the Philippine sea plate. Tectonics, 3, 555-575, 1984.

Rozhdestvenskiy, V.S., The role of wrench faults in the structure of Sakhalin, Geotectonics, 16, 323-332, 1982. 
Rozhdestvenskiy, V. S., Evolution of the Sakhalin fold system, Teclonophysics, 127, 331-339, 1986.

Sato, H., Degree of deformation of Late Cenozoic strata in the Northeast Honshu arc, Mem. Geol. Soc. Jpn., 32, 257-268, 1989.

Savostin, L.A., and A. M. Karasik, Recent plate tectonics of the Arctic basin and of northeastem Asia, Tectonophysics, 74, 111 145, 1981.

Savostin, L., L. Zonenshain, and B. Baranov, Geology and plate tectonics of the Sea of Okhotsk, in: Geodynamics of the Western Pacific and Indonesion Region, Geodyn. Ser. vol. 11, W.C.T. Hilde and S. Uyeda, Pp. 343354, AGU, Washington, D.C., 1983.

Seno, T., Is Northem Honshu a microplate?, Tectonophysics, 115, 177-196, 1985.

Sillitoe, R. H., Metallogeny of an Andean-Lype continental margin in South Korea, implications for opening of the Japan Sea, in Island Arcs, Deep Sea Trenches and Back Arc Basins, Maurice Ewing Ser., vol. 1, edited by M. Talwani and W.C. Pitman III, Pp. 303-310, AGU, Washington, D.C., 1977.

Sugi, N., K. Chinzei, and S. Uyeda, Vertical crustal movements of northeast Japan since Middle Miocene. in: Geodynamics of the Western Pacific and Indonesian Region, Geodyn. Ser., vol. 11, W.C.T. Hilde and S. Uyeda, pp. 317329, AGU, Washington, D.C., 1983.

Suyehiro, K., et al., Proc. Ocean Drilling Program Initial Rep., 128, 1990.
Suzuki, K., On the Late Cenozoic history in the southern part of nonheast Honshu in Japan, Mem. Geol. Soc. Jpn., 32, 97-112, 1989.

Taira, A., H. Tokuyama, and W. Soh, Accretion tectonics and evolution of Japan, In The Evolution of the Pacific Ocean Margin, edited by $Z$ Ben-Avraham, pp. 160-123, Oxford University Press, 100-123, New York, 1989.

Takeuchi, A., On the episodic vicissitude of tectonic stress field of the Cenozoic northaest Honshu arc, Japan, in Formation of Active Ocean Margins, edited by N. Nasu et al., Terrapub, pp. 443-468, Tokyo, , 1985.

Tamaki, K., Two modes of back arc spreading. Geology, 13, 475-478, 1985.

Tamaki, K., Geological structure of the Japan sea and its tectonic implications, Bull. Geol. Surv. Jpn., 39, 269-365, 1988.

Tamaki, K., Proc. Ocean Drilling Program Initial Rep., 127, 1990.

Tsuchiya, N., Submarine basalt volcanism of Miocene Aozswa formation in the AkitaYamagaca oil field basin, back-arc region of Northeast Japan, Mem. Geol. Soc. Jpn., 32, 399-408, 1989.

Tsuchiya, N., Middle Miocene back-arc rift magmatism of basalt in the NE Japan arc, Bull. Geol. Surv. Jpn., 41, 473-505, 1990.

Watanabe, Y., Deformation structure of the Uenshiri horst in the Hidaka belt, Central Hokkaido, J. Geol. Soc. Jpn., 94, 527-533, 1988.
Watanabe, $Y_{\text {., }}$ and $K$. Iwata, The age of the Miocene Kamishiyubetsu formation in northern Hokkaido and the basins formed by lectonic movements, J. Geol. Soc. Jpn., 91, 427-430, 1985.

Yamagishi, H., and Y. Watanabe, Change of stress field of Late Cenozoic Southwest Hokkaido, Japan, - investigation of geologic faults, dykes, ore veins and active faults, Monogr. Geol. Collab. Jpn., 31, 321-332. 1986.

Yamaji, A., Geology of the Atsumi area and Early Miocene rifling in the Uetsu District, Northeast Japan, Mem. Geol. Soc. Jpn., 32, 305-320, 1989.

Yamaji, A., Rapid intra-arc rifting in Miocene northeast Japan, Tectonics, 9, 365-378, 1990.

M. Foumier, P. Huchon, and L. Jolivet, Département de Géologie, Ecole Normale Supérieure, 24 Rue Lhomond, 75231 Paris cedex, France.

L. S. Oscorbin, V. S. Rozdhdestvenskyi, and K.F. Sergeyev, Institute of Marine Geology and Geophysics, Far East Science Center, YuzhnoSakhalinsk, USSR.

(Received January 23, 1991: revised December 18, 1991; accepted February 10, 1992.) 